\title{
Histomorphological Effect of Centella Asiatica on Swiss Albino Mice Brain upon Ketamine Anesthetic Induced Memory Impairment
}

\author{
Mohammad Asaduzzaman ${ }^{1} \quad$ Md. Alauddin $^{2} \quad$ Farha Matin Juliana $^{3} \quad$ Mohammod Johirul Islam $^{4}$ \\ Farzana Hafiz ${ }^{5} \quad$ Aradhan Sarkar*6 \\ 1.Department of Biochemistry, Primeasia University, Banani, Dhaka, Bangladesh \\ 2.Department of Biotechnology and Genetic Engineering, University of Development Alternative, Bangladesh \\ 3.Department of Biochemistry and Molecular Biology, Jahangirnagar University, Savar, Dhaka, Bangladesh \\ 4.Department of Biochemistry and Molecular Biology, Mawlana Bhashani Science and Technology University, \\ Tangail, Bangladesh \\ 5.Pathology and Laboratory Medicine, Square Hospital, Dhaka, Bangladesh \\ 6.Department of Biotechnology and Genetic Engineering, Noakhali Science and Technology University, \\ Noakhali, Bangladesh
}

\begin{abstract}
Abstracrt
Introduction: Ketamine is a medication mainly used for starting and maintaining anesthesia. It induces a trancelike state while providing pain relief, sedation and memory loss. Ketamine causes morphological changes in the neuronal cells of growing rodent. Centella asiatica is used for memory enhancement in the ayurvadic system of medicine. It has been shown to be useful in improving learning and memory. Centella asiatica leaf extract treatment enhances neuronal dendritic arborization in hippocampus of growing rodent.Materials and Methods: Swiss albino mice were used for our experiment. Ketamine was administered subcutaneously and Centella-asiatica leaf extract was administered orally. Mice brain collected, grossed, processed and finally stained by Hematoxylin and Eosin (H\&E) staining process for viewing cellular and tissue structure detail by pathologists. Results: Focal cellular damage was seen in CA2 and CA4 area of cornu ammonis (CA), expanded cytoplasmic eosinophilia saw in the pyramidal cell layers (PY) of CA2, expanded cytoplasmic eosinophilia found with obliteration of neurifibrilary components (NFE), typical pyramidal cell (NPY) in the CA4, ordinary engineering of dentate granule layers (DG) and hardly any cells were found with diminished size in regards to granule layer cells (GC) in the brain hippocampus of the high ketamine prompted mice. In the mouse brain hippocampus for high ketamineCentella asiatica summed up cell destruction found in the CA1 to CA4 of CA. Expanded cytoplasmic eosinophilia found in the pyramidal cell layers of CA2 than high dose ketamine group. The vast majority of the pyramidal cells were necrotic (PYN) with annihilation of neurofibrilary components (NFE) in the pyramidal cell layers of CA4.

Keywords: Centella asiatica, Ketamine and memory impairment.
\end{abstract}

DOI: $10.7176 /$ ALST/82-02

Publication date:October $31^{\text {st }} 2020$

\section{Introduction}

Anesthetics activate memory-loss receptors in the brain, ensuring that patients don't remember traumatic events during surgery. The central nervous system has many parts. Hippocampus belongs to the limbic system and plays important role in the integration of information from short term memory to long term memory.[1] The dentate gyrus is part of a brain region known as the hippocampus (part of the hippocampal formation). The dentate gyrus is thought to contribute to the formation of new episodic memories, [2, 3] the spontaneous exploration of novel environments, [3] and other functions.[4] It is notable as being one of a select few brain structures currently known to have significant rates of adult neurogenesis in many species of mammals, from rodents to primates[5] (other sites include the subventricular zone of the striatum,[6] and cerebellum[7]. However, whether neurogenesis exists in the adult human dentate gyrus is currently a matter of debate. [8, 9]

Ketamine is a medication mainly used for starting and maintaining anesthesia.[10] It induces a trance-like state while providing pain relief, sedation, and memory loss.[11] Other uses include for chronic pain, sedation in intensive care, and depression.[12-15] Heart function, breathing, and airway reflexes generally remain functional.[11] Effects typically begin within five minutes when given by injection, and last up to about 25 minutes.[10] ketamine is used in medicine as an anesthetic;[16] however, due to the hallucinations it may cause, it is not typically used as a primary anesthetic, although it is the anesthetic of choice when reliable ventilation equipment is not available.

Ketamine is frequently used in severely injured people and appears to be safe in this group.[17] A 2011 clinical practice guideline supports the use of ketamine as a dissociative sedative in emergency medicine.[11] It is the drug of choice for people in traumatic shock who are at risk of hypotension.[18] Low blood pressure is harmful in people with severe head injury[19] and ketamine is least likely to cause low blood pressure, often even able to 
prevent it.[20, 21]

The effect of ketamine on the respiratory and circulatory systems is different from that of other anesthetics. When used at anesthetic doses, it will usually stimulate rather than depress the circulatory system.[22] It is sometimes possible to perform ketamine anesthesia without protective measures to the airways.[23] Ketamine is considered relatively safe because protective airway reflexes are preserved.[24]

Ketamine is used as a bronchodilator in the treatment of severe asthma.[25] However, evidence of clinical benefit is limited.[25, 26]

Antagonism of the NMDA receptor is thought to be responsible for the anesthetic, amnesic, dissociative, and hallucinogenic effects of ketamine.[27] The mechanism(s) of action for the antidepressant effects of ketamine at lower doses have yet to be fully elucidated.[28] NMDA receptor antagonism results in analgesia by preventing central sensitization in dorsal horn neurons; in other words, ketamine's actions interfere with pain transmission in the spinal cord.[28] Inhibition of nitric oxide synthase lowers the production of nitric oxide- a gasotransmitter involved in pain perception, hence further contributing to analgesia.[29]

Ketamine produces measurable changes in peripheral organ systems, including the cardiovascular, gastrointestinal, and respiratory systems:[29]

- Cardiovascular: Ketamine stimulates the sympathetic nervous system, resulting in cardiovascular changes.

- Gastrointestinal: Ketamine produces nausea and vomiting in 15 to 25\% of individuals at anesthetic doses.[29]

- Respiratory: Ketamine causes bronchodilation.[30] Several mechanisms have been hypothesized to explain this effect.[30]

Drowsiness, dissociation, and psychosis-like effects (e.g., hallucinations, delirium) are reported in patients treated with ketamine starting at circulating concentrations of around 50 to $200 \mathrm{ng} / \mathrm{mL}(210-841 \mathrm{nM})$, while analgesia begins at levels of approximately 100 to $200 \mathrm{ng} / \mathrm{mL}(421-841 \mathrm{nM})$.[31, 32] The typical intravenous antidepressant dosage of ketamine used to treat depression is low and results in maximal plasma concentrations of 70 to $200 \mathrm{ng} / \mathrm{mL}$ (294-841 nM).[33] Circulating concentrations of around 2,000 to 3,000 ng/mL $(8,413-12,620$ $\mathrm{nM}$ ) are employed during anesthesia, and patients may start to awaken once levels of ketamine have decreased to about 500 to $1,000 \mathrm{ng} / \mathrm{mL}(2,103-4,207 \mathrm{nM})$.[31, 32] There is wide variation in the peak concentrations of ketamine that have been reported in association with anesthesia in the literature, with values ranging from 2,211$3,447 \mathrm{ng} / \mathrm{mL}(9,300-14,500 \mathrm{nM})$ to as high as $22,370 \mathrm{ng} / \mathrm{mL}(94,100 \mathrm{nM})$.[34, 35] Bioactive concentrations of ketamine are lower than total plasma levels due to plasma protein binding,[34] although plasma protein binding is relatively low with ketamine (approximately 12 to $47 \%$ protein-bound).[36] Concentrations of ketamine in the brain have been reported to be several-fold higher than in plasma.[35]

An increasing number of in vitro and in vivo studies suggest that anesthesia and surgery could be risk factors for later cognitive impairment in the young and aged brain. General anesthesia has been shown to impair spatial memory in rats and this performance is dependent on hippocampal function and postnatal hippocampal neurogenesis. Anesthetic induced alteration of one or more stages of postnatal hippocampal neurogenesis may in part explain this cognitive impairment following anesthesia.[37]

Centella asiatica is common herbaceous forest plant. It is used as vegetable and medicine. It is small size plant. Its leaves are green and flower is white and pinkish. It is indigenous to the Indian subcontinent.[38, 39] Centella asiatica used to treat various diseases.[40] It is used in headaches, nausea cold fever and drowsiness. Another important use of it is for memory enhancement which used in the ayurvadic system of medicine. It has been shown to be useful in improving learning and memory.[40] In addition the plant is also used in mentally retarded children to improve general mental ability and in people suffering from cognitive disorders.[41] The fresh leaf juice (extract) of Centella asiatica has been claimed to improved learning and memory in different clinical studies.[42]

Excessive stress causes neuronal degeneration. Stress like prolong and repeated use of anesthetic drug. Ketamine causes morphological changes in the neuronal cells of growing rodent.[43] On the other hand, Centella asiatica leaf extract treatment enhances neuronal dendritic arborization in hippocampus of growing rodent.[43] But the cytoprotective property of Centella asiatica on the morphology of the hippocampal neuron has not been reported.[44] In this study numbers of mice were selected to receive high dose ketamine to induce anesthesia which is considered as stress, repeatedly for seven days in one group. In other group of mice received high dose ketamine with extract of Centella asiatica. Our aim was to observe types of morphological changes occurs in neurons of mice's hippocampus after using high dose ketamine and high dose ketamine with high dose extract of Centella aisatica.

\section{MATERIALS AND METHODS}

\section{Animal model}

15 Swiss albino mice were collected from animal resource department of ICDDR,B, Mohakhali Dhaka-1212. The mice were stored in metallic cage (5mice / cage) and given corn and water. Nearly identical weight mice were randomly divided in the three groups. Group A became control group, groups B changed into for high dose of 
ketamine and group $\mathrm{C}$ was for high dose ketamine with Centella asiatca extract. Mice are most typically used animal models for reading human disease for plenty proper reasons. Mice are biologically very just like human.

\section{Preparation of extract powder of Centella asiatica}

Green Centella asiatica sample was collected from Mohammadpur Town Hall Kacha Bazar Dhaka, Bangladesh and this was certified by National Herbarium, Mirpur-2, Dhaka, Bangladesh. The sample was cleaned and washed by water to remove dirty parts. Then the sample was dried under sunlight and converted to powder by mechanical blender and preserved in an air tight container at room temperature until extraction. 50gram dried powder was put into a glass beaker and added $250 \mathrm{ml}$ methanol. Slow stirring was continued with a glass rod for one hour to mix up methanol and fine dried powder. The beaker was covered with aluminum foil and left for 48 hours. The mixture was filtered with thin cloth (white color) and the extract was taken to the water bath till dried extracts (crude drug) were obtained. The Temperature was always maintained at $40^{\circ} \mathrm{C}$ and finally the extract was collected by spatula in a marked glass vial. A total of 4 gram dry powder extract was found and put into glass vial. The extract vial was kept in a refrigerator at $4^{\circ} \mathrm{C}$ temperature.

\section{Oral preparation of Centella asiatica powder extract and dosage form}

4 gram extract powder was dissolved in $4 \mathrm{ml} 1 \%$ DMSO. Final concentration of Centella asiatica powder was $1 \mu \mathrm{g} / \mu \mathrm{l}$. This solution was administered orally. $2 \mu \mathrm{l}$ solution per gram body weight was administered for each mouse those were dedicated for Centella asiatica. Same dosage form of Centella asiatica was used for the mice those were subjected for combined action of Centella asiatica and ketamine.

\section{Injectable preparation of Ketamine and dosage form}

Ketalar inection (ketamine $50 \mathrm{mg} / \mathrm{ml}$ ) of Popular Pharmaceutical Limited, Bangladesh was used as general anesthetics. Ketamine is a noncompetitive N-methyl-D-aspartate receptor antagonist that blocks glutamate. It has a direct action on the cortex and limbic system. It produces a cataleptic-like state wherein the patient is withdrawn from the surrounding environment. $2 \mu \mathrm{l}$ ketamine injection per gram body weight was administered subcutaneously for each mouse those were dedicated for ketamine. Like Centella asiatica same dosage form of ketamine was used for the mice those were subjected for combined action of Centella asiatica and ketamine.

\section{Mice brain collection}

At fast the Swiss albino mice were slaughtered with a sharp knife. Then removed the upper skin from the head and removed the skull by forceps and separated the brain. Separated brains then dipped into $10 \%$ buffer formalin fixative and sent to the laboratory for grossing.

\section{Brain grossing}

Control group: Brain sample was received in $10 \%$ buffer formalin fixative container with identification number. Brain weight was $10 \mathrm{gm}$ and dimension was $1.5 \times 1.2 \times .0 .6 \mathrm{~cm}$. Brain was sectioned into seven parts A1 to A7. At A3 hippocampus was identified.

High dose ketamine: Brain sample was received in $10 \%$ buffer formalin fixative container with identification number. Brain weight was $11 \mathrm{gm}$ and dimension was $1.5 \mathrm{x} 1.4 \mathrm{x} .0 .6 \mathrm{~cm}$. Brain was sectioned into seven parts A1 to A7. At A3 hippocampus was identified.

Ketamine with extract: Brain sample received in $10 \%$ buffer formalin fixative container with identification number. Brain weight was $9 \mathrm{gm}$ and dimension was $1.3 \times 1.0 \mathrm{x} .0 .6 \mathrm{~cm}$. Brain was sectioned into seven parts A1 to A7. At A3 hippocampus was identified.

\section{Brain tissue processing}

Brain tissue processing was accomplished by following a well known procedure written by Geoffrey Rolls for Leica Biosystems, Wetzlar, Germany.[55][56][57][58] (Source: https://www.leicabiosystems.com/knowledgepathway/an-introduction-to-specimen-processing/)

\section{Brain tissue staining}

Hematoxylin and Eosin (H\&E) staining process was used for viewing cellular and tissue structure detail by pathologists. Brain tissue staining was accomplished by following a well known protocol written by Cindy Sampias and Geoffrey Rolls for Leica Biosystems, Wetzlar, Germany. (Source: https://www.leicabiosystems.com/knowledge-pathway/he-staining-overview-a-guide-to-best-practices/)

\section{Results}

In our study we set three groups of Swiss albino mice of similar weight. One group was considered as control, one group was considered for high dose ketamine subcutaneous administration and last group was selected for high 
dose ketamine subcutaneous administration with high dose Centella asiatica oral administration.

We found dimension change in the brain of the three mice groups. High dose ketamine with high dose Centella asiatica administered mice group found with reduced dimension, $1.3 \times 1.0 \times .0 .6 \mathrm{~cm}$, then followed control group, $1.5 \times 1.4 \times 0.6 \mathrm{~cm}$, and high dose ketamine group, $1.5 \times 1.2 \times 0.6 \mathrm{~cm}$.

Starting at the dentate gyrus and working inward along the S-curve of the hippocampus means traversing a series of narrow zones. The first of these, the dentate gyrus (DG), is actually a separate structure, a tightly packed layer of small granule cells wrapped around the end of the hippocampus proper, forming a pointed wedge in some cross-sections, a semicircle in others. Next come a series of Cornu Ammonis (CA) areas: first CA4 (which underlies the dentate gyrus), then CA3, then a very small zone called CA2, then CA1. The CA areas are all filled with densely packed Pyramidal cells similar to those found in the neocortex. After CA1 comes an area called the subiculum. After this comes a pair of ill-defined areas called the presubiculum and parasubiculum, then a transition to the cortex proper (mostly the entorhinal area of the cortex). Most anatomists use the term "hippocampus proper" to refer to the four CA fields, and hippocampal formation to refer to the hippocampus proper plus dentate gyrus and

subiculum.[59]

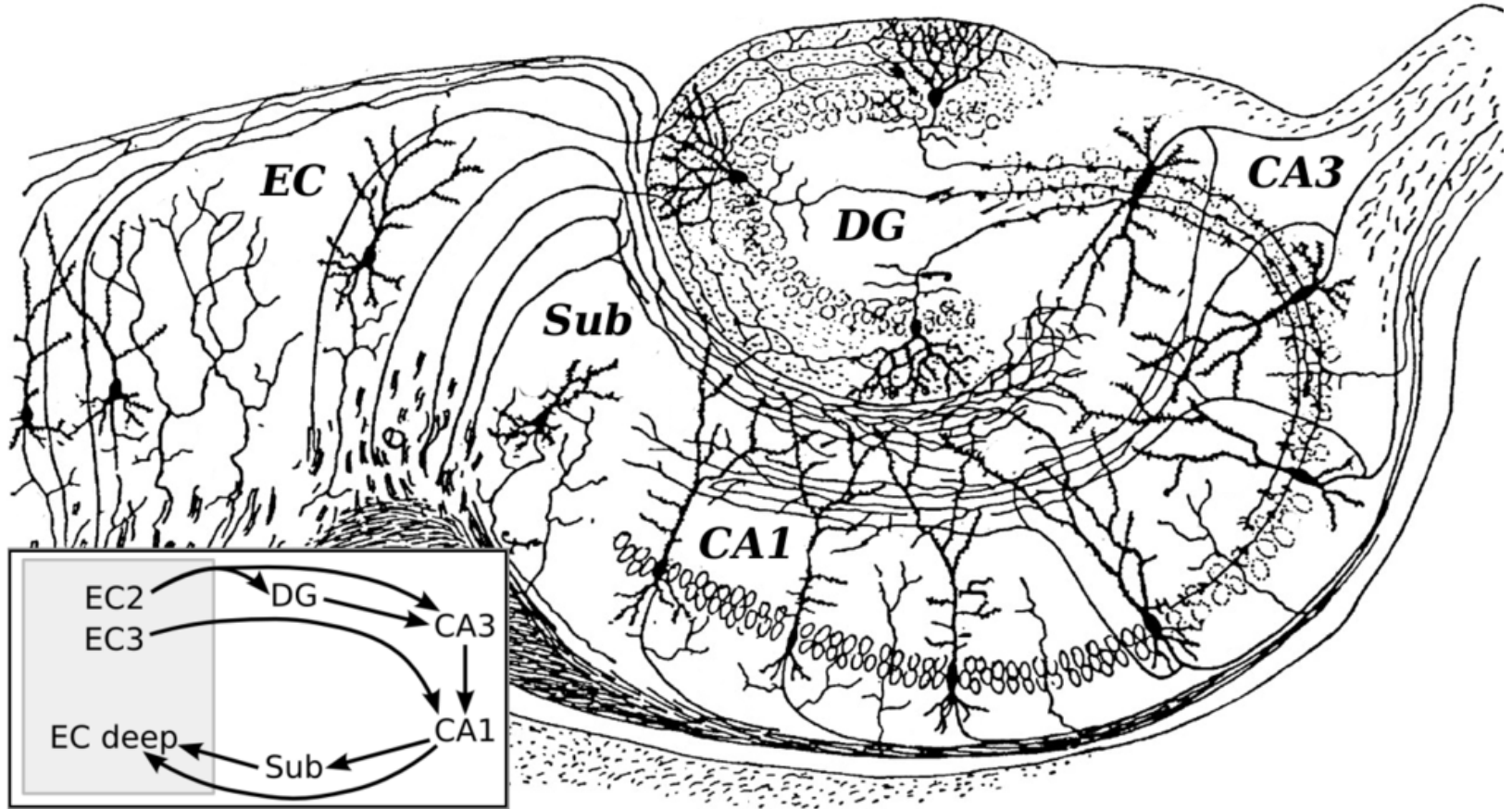

Figure-1: Basic circuit of the hippocampus, shown using a modified drawing by Ramon y Cajal. DG: dentate gyrus. Sub: subiculum. EC: entorhinal cortex 


\section{Control}

a. Cornu Ammonis (CA2 \& CA4)

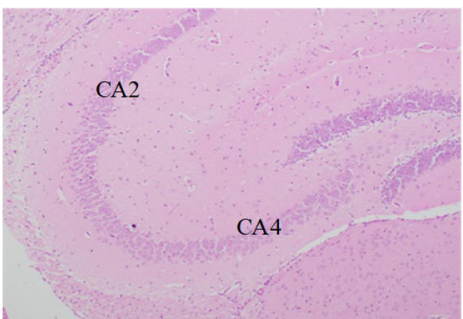

(Normal architecture)

b. CA2: Pyramidal cell layers (PY)

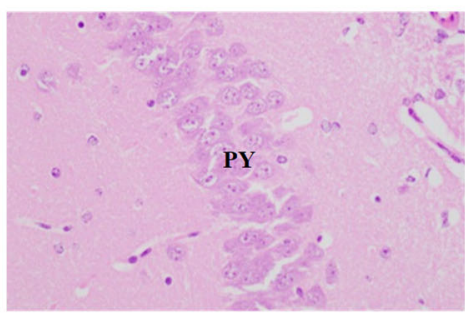

c. CA4: Pyramidal cell layers (PY)

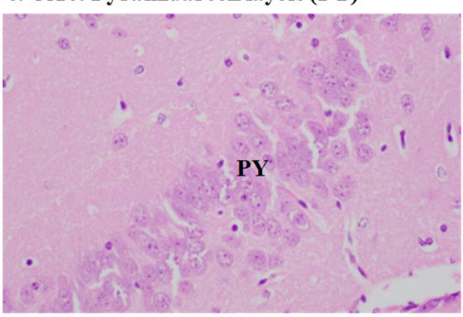

d. Denta te granule layers (DG)

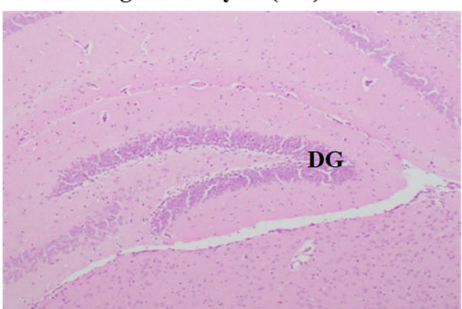

e. Granule layers cell (GC)

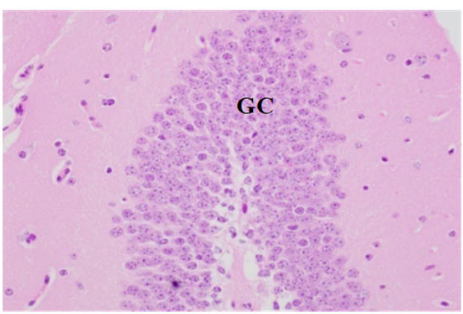

(Normal architecture)

\section{High Ketamine}

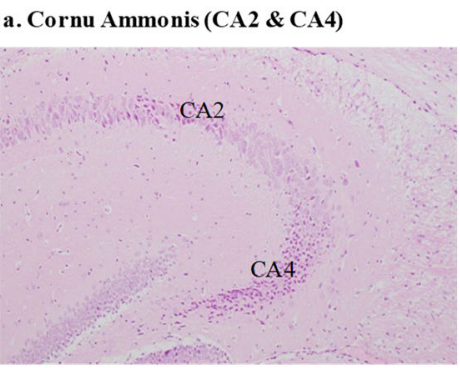

(Focal cellular reduction)

b. CA2: Pyramidal cell layers (PY)

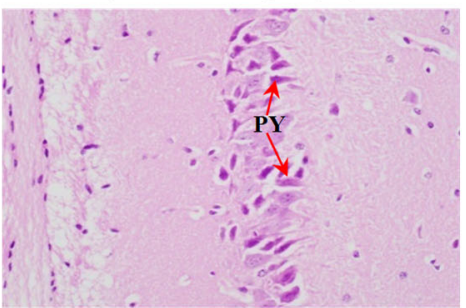

(Increased cytoplasmic eo sinophilia)

c. CA4: Many Pyramidal cell (PY)

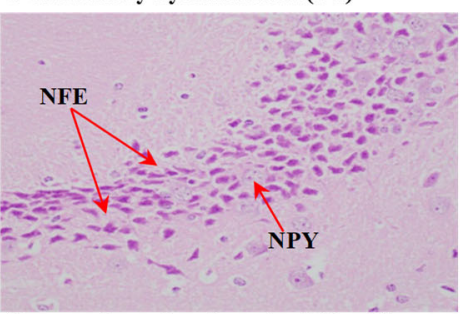

(Increased cy toplasmic eosinophilia with des truction of neurofibrilary elements (NFE)

Normal pyramidal cell (NPY))

d. Dentate granule layers (DG)

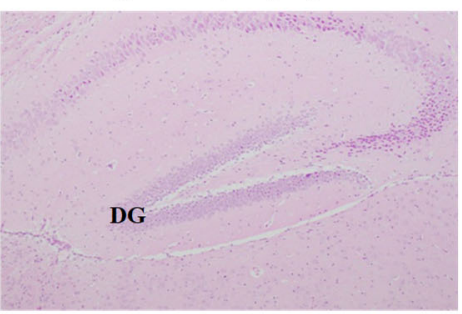

(Normal architecture)

e. Granule layers cells (GC)

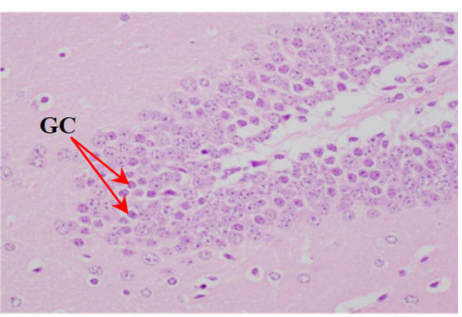

(Few cell's size reduced)
High Ketamine+Centella asiatica

a. Cornu Ammonis (CA1-CA4)

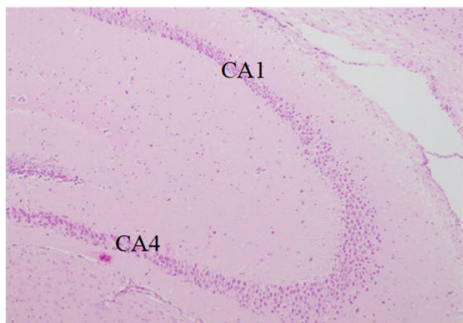

(Generalized cellular reduction)

b. CA2: Pyramidal cell layers (PY)

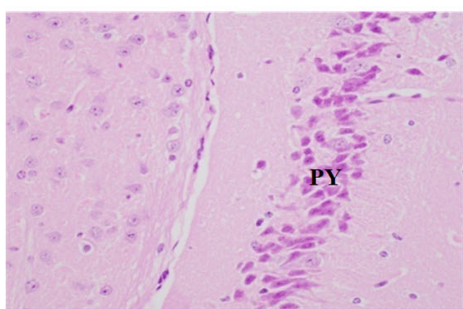

(Increased cytoplasmic eosinophilia)

c. CA4: Many Pyramidal cell (PY)

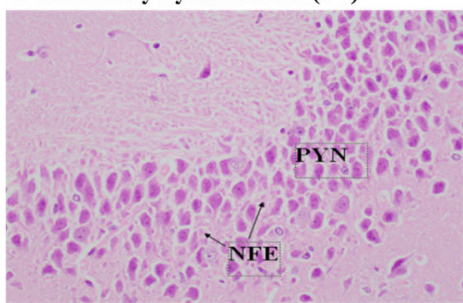

(Most of the Pyramidal cell are necrotic

(PYN) with destruction of neurofibrilary

elements (NFE))

d. Dentate granule layers (DG)

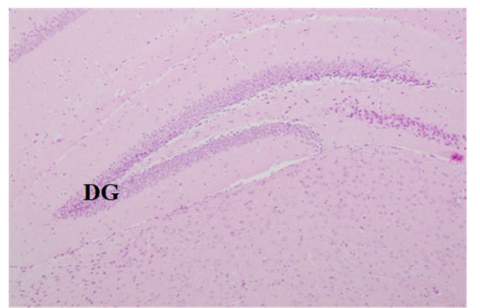

e. Granule layers cells (GC)

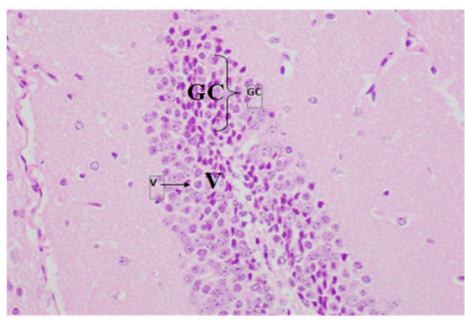

(Shrinkage of Granule cells (GC) layers with reduction of cell's s size andminimal vaculation(V))

Figure 2-Effect of high dose ketamine and high dose ketamine plus high dose Centella asiatica on mice brain

Figure-2 showed the morphophological effect of high dose ketamine and high dose ketamine with Centella asiatica on dentate gyrus.

We observed focal cellular reduction in CA2 and CA4 region of cornu ammonis (CA), increased cytoplasmic eosinophilia observed in the pyramidal cell layers (PY) of CA2, increased cytoplasmic eosinophilia found with destruction of neurifibrilary elements (NFE), normal pyramidal cell (NPY) in the CA4, normal architecture of 
dentate granule layers (DG) and few cells were found with reduced size regarding granule layer cells (GC) in the brain of the high ketamine induced mice.

For high ketamine-Centella asiatica mice group generalized cellular reduction found in the CA1 to CA4 region of cornu ammonius. Increased cytoplasmic eosinophilia found in the pyramidal cell layers of CA2 than high dose ketamine. Most of the pyramidal cells were necrotic (PYN) with destruction of neurofibrilary elements (NFE) in the pyramidal cell layers of CA4.

\section{Discussion}

As manufactured medications can prompt lung and kidney lethality, numerous clinicians and researchers have looked enthusiastically for different choices to treat their patients. Home grown plants which are normally wealthy in remedial worth, more eco-accommodating and have lesser symptoms have been consequently read for usage in therapeutic applications. This has brought Centella asiatica, which is known to have memory and subjective improvement, into logical examinations for nerve recovery and neurological capacities before helpful use.

Research on the neuroregenerative limit of Centella asiatica on the focal sensory system has been broadly directed, concentrating on synapses. Soumyanath et al. [45] uncovered the capacity of asiatic acid (AA) to advance the lengthening of neurites utilizing an in vitro test model. They additionally saw that this activity could be coanimated with the other dynamic mixes found in the herb that have synergistic impacts with AA. In parallel with this, Rao et al. [42] announced that crisp Centella asiatica leaf separate fundamentally expands the dendritic arborisation of hippocampal CA3 neurons in vivo. In perspective on Centella asiatica as a nerve tonic [46], it is accepted to effectsly affect the fringe sensory system as well. Nonetheless, further examinations are expected to bring it into proof, as the writing on such sensory system benefits is excessively constrained to date.

Since variation of extract constituents can lead to various complications, scientists from Thailand have recently established a standardized extract of Centella asiatica known as ECa 233 [47]. The extract was clearly demonstrated to have stimulatory effects on the elongation of neuroblastoma cell neurites at a maximum dose of $100 \mu \mathrm{g} / \mathrm{mL}$ [48]. In spite of dendritic arborisation, this particular herb also exhibits neuroprotective properties. Zhang and his colleagues [49] have recently disclosed that AA ameliorates the action of C2-ceramide in inducing neuronal cell death in a concentration-dependent manner.

Despite the fact that the fundamental mechanisms whereby the herb applies its belongings are ineffectively comprehended, the previously mentioned properties synchronize with the dominance of this herb to phosphorylate a few flagging pathways to intercede its capacities. In fact, the components associated with neurite advancement are very mind boggling, yet the MEK/ERK and PI3/Akt signaling pathways have increased noteworthy consideration [50]. A past report explained that AA in Centella asiatica evokes its neuroregenerative impact by means of the MAP kinase pathway [45]. In concurrence with this, Wanakhachornkrai et al. [48] additionally uncovered that ECa 233 is MEK/ERK-and PI3K/AKT-subordinate in advancing the extension of neurites.

Other than that, Omar et al. [51] as of late uncovered the guideline of the caspase-9 pathway by Centella asiatica in adjusting neuron cell endurance against apoptosis. In this investigation, l-buthionine-(S,R)- sulfoximine (BSO)- incited human neuron cell demise was treated with ethanolic concentrate of Centella asiatica in the scope of $5-500 \mu \mathrm{g} / \mathrm{mL}$. They found that, at low concentrations, this extract can ensure neuron cells against oxidative pressure. This may point to the limit of this herb in restraining the caspase- 9 pathway by blocking the creation of proapoptotic proteins, advancing antiapoptotic proteins and copying the last mentioned [43, 44]. Despite the fact that this mechanism is evidently centered around neuroprotective impacts against apoptosis, such a system could be a subset in the recovery and upgrade of nerve cell wounds. All the previously mentioned mechanisms cover each other in keeping up nerve cell development.

In the above discussion we found beneficiary role of Centella asiatica regarding neuroprotection, neuroregeneration, dendritic arborisation, antiapoptosis. We did not find any data regarding co-administration of Centella asiatica with ketamine or any other anesthetics. In our study we found no positive role of Centella asiatica with ketamine. In the ketamine induced brain we found increased cytoplasmic eosinophilia in the pyramidal cell layers of CA2. Most of the pyramidal cells were found necrotic (PYN) with destruction of neurofibrilary elements (NFE) in the pyramidal cell layers of CA4.

\section{Conclusion}

In the combined action of ketamine and Centella asiatica, Centella asiatica exerted no physiologically positive impact in the mice brain hippocampus. Hippocampus found with increased cytoplasmic eosinophilia, necrosis with decreased neurofibrilary elements (NFE)

\section{References}

1. Torrico TJ, Abdijadid S: Neuroanatomy, Limbic System. In: StatPearls [Internet]. StatPearls Publishing; 2019.

2. Amaral DG, Scharfman HE, Lavenex P: The dentate gyrus: fundamental neuroanatomical organization 
(dentate gyrus for dummies). Progress in brain research 2007, 163:3-790.

3. Saab BJ, Georgiou J, Nath A, Lee FJ, Wang M, Michalon A, Liu F, Mansuy IM, Roder JC: NCS-1 in the dentate gyrus promotes exploration, synaptic plasticity, and rapid acquisition of spatial memory. Neuron 2009, 63(5):643-656.

4. Scharfman HE: The dentate gyrus: a comprehensive guide to structure, function, and clinical implications, vol. 163: Elsevier; 2011.

5. Cameron HA, Mckay RD: Adult neurogenesis produces a large pool of new granule cells in the dentate gyrus. Journal of Comparative Neurology 2001, 435(4):406-417.

6. Ernst A, Alkass K, Bernard S, Salehpour M, Perl S, Tisdale J, Possnert G, Druid H, Frisén J: Neurogenesis in the striatum of the adult human brain. Cell 2014, 156(5):1072-1083.

7. Ponti G, Peretto P, Bonfanti L: Genesis of neuronal and glial progenitors in the cerebellar cortex of peripuberal and adult rabbits. PLoS One 2008, 3(6):e2366.

8. Sorrells SF, Paredes MF, Cebrian-Silla A, Sandoval K, Qi D, Kelley KW, James D, Mayer S, Chang J, Auguste KI: Human hippocampal neurogenesis drops sharply in children to undetectable levels in adults. Nature 2018, 555(7696):377.

9. Boldrini M, Fulmore CA, Tartt AN, Simeon LR, Pavlova I, Poposka V, Rosoklija GB, Stankov A, Arango V, Dwork AJ: Human hippocampal neurogenesis persists throughout aging. Cell stem cell 2018, 22(4):589599. e585.

10. Das B, Kumar US, Aditya AK, Mishra D: Comparative administration of ketamine-dexmedetomidine \& Ketamine: Propofol for sedation during upper gastrointestinal endoscopy in children.

11. Green SM, Roback MG, Kennedy RM, Krauss B: Clinical practice guideline for emergency department ketamine dissociative sedation: 2011 update. Annals of emergency medicine 2011, 57(5):449-461.

12. Zgaia AO, Irimie A, Sandesc D, Vlad C, Lisencu C, Rogobete A, Achimas-Cadariu P: The role of ketamine in the treatment of chronic cancer pain. Clujul Medical 2015, 88(4):457.

13. Zapantis A, Leung S: Tolerance and withdrawal issues with sedation. Critical Care Nursing Clinics 2005, 17(3):211-223.

14. Zhang K, Hashimoto K: An update on ketamine and its two enantiomers as rapid-acting antidepressants. Expert review of neurotherapeutics 2019, 19(1):83-92.

15. Kraus C, Rabl U, Vanicek T, Carlberg L, Popovic A, Spies M, Bartova L, Gryglewski G, Papageorgiou K, Lanzenberger R: Administration of ketamine for unipolar and bipolar depression. International journal of psychiatry in clinical practice 2017, 21(1):2-12.

16. Heshmati F, ZEYNALI M, NOUROUZINIA H, ABBASIVASH R, MAHOURI A: Use of ketamine in severe status asthmaticus in intensive care unit. 2003.

17. Cohen L, Athaide V, Wickham ME, Doyle-Waters MM, Rose NG, Hohl CM: The effect of ketamine on intracranial and cerebral perfusion pressure and health outcomes: a systematic review. Annals of emergency medicine 2015, 65(1):43-51. e42.

18. Kurdi MS, Theerth KA, Deva RS: Ketamine: current applications in anesthesia, pain, and critical care. Anesthesia, essays and researches 2014, 8(3):283.

19. Manley G, Knudson MM, Morabito D, Damron S, Erickson V, Pitts L: Hypotension, hypoxia, and head injury: frequency, duration, and consequences. Archives of Surgery 2001, 136(10):1118-1123.

20. Hemmingsen C, Nielsen JK: Intravenous ketamine for prevention of severe hypotension during spinal anaesthesia. Acta anaesthesiologica scandinavica 1991, 35(8):755-757.

21. Wong DH, Jenkins LC: The cardiovascular effects of ketamine in hypotensive states. Canadian Anaesthetists' Society Journal 1975, 22(3):339-348.

22. Adams H: S-(+)-Ketamin Kreislaufinteraktionen bei totaler intravenöser Anästhesie und Analgosedierung. Der Anaesthesist 1997, 46(12):1081-1087.

23. Adriani J: The Pharmacology of Anesthetic Drugs. Anesthesia \& Analgesia 1941, 20(5):105.

24. Wong JJ, Lee $\mathrm{JH}$, Turner DA, Rehder $\mathrm{KJ}$ : A review of the use of adjunctive therapies in severe acute asthma exacerbation in critically ill children. Expert review of respiratory medicine 2014, 8(4):423-441.

25. Goyal S, Agrawal A: Ketamine in status asthmaticus: a review. Indian journal of critical care medicine: peer-reviewed, official publication of Indian Society of Critical Care Medicine 2013, 17(3):154.

26. Jat KR, Chawla D: Ketamine for management of acute exacerbations of asthma in children. Cochrane Database of Systematic Reviews 2012(11).

27. Kohrs R, Durieux ME: Ketamine: teaching an old drug new tricks. Anesthesia \& Analgesia 1998, 87(5):1186-1193.

28. Browne CA, Lucki I: Antidepressant effects of ketamine: mechanisms underlying fast-acting novel antidepressants. Frontiers in pharmacology 2013, 4:161.

29. Aroni F, Iacovidou N, Dontas I, Pourzitaki C, Xanthos T: Pharmacological aspects and potential new clinical applications of ketamine: reevaluation of an old drug. The Journal of Clinical Pharmacology 
2009, 49(8):957-964.

30. $\mathrm{Xu}$ J, Lei H: Ketamine-An Update on Its Clinical Uses and Abuses. CNS neuroscience \& therapeutics 2014, 20(12):1015-1020.

31. Sleigh J, Harvey M, Voss L, Denny B: Ketamine-More mechanisms of action than just NMDA blockade. Trends in anaesthesia and critical care 2014, 4(2-3):76-81.

32. Schüttler J, Schwilden H: Modern Anesthetics. Handbook of Experimental Pharmacology: Springer; 2008.

33. Sanacora G, Frye MA, McDonald W, Mathew SJ, Turner MS, Schatzberg AF, Summergrad P, Nemeroff CB: A consensus statement on the use of ketamine in the treatment of mood disorders. JAMA psychiatry 2017, 74(4):399-405.

34. Hirota K, Okawa H, Appadu BL, Grandy D, Devi LA, Lambert DG: Stereoselective interaction of ketamine with recombinant mu, kappa, and delta opioid receptors expressed in Chinese hamster ovary cells. Anesthesiology 1999, 90(1):174-182.

35. Kapur S, Seeman P: NMDA receptor antagonists ketamine and PCP have direct effects on the dopamine D 2 and serotonin 5-HT 2 receptors-implications for models of schizophrenia. Molecular psychiatry 2002, 7(8):837.

36. Yagiela JA, Dowd FJ, Johnson B, Mariotti A, Neidle EA: Pharmacology and Therapeutics for DentistryE-Book: Elsevier Health Sciences; 2010.

37. Erasso DM, Camporesi EM, Mangar D, Saporta S: Effects of isoflurane or propofol on postnatal hippocampal neurogenesis in young and aged rats. Brain research 2013, 1530:1-12.

38. Bylka W, Znajdek-Awiżeń P, Studzińska-Sroka E, Brzezińska M: Centella asiatica in cosmetology. Postepy Dermatol Alergol 2013, 30(1):46-49.

39. Mukherjee S, Dugad S, Bhandare R, Pawar N, Jagtap S, Pawar PK, Kulkarni O: Evaluation of comparative free-radical quenching potential of Brahmi (Bacopa monnieri) and Mandookparni (Centella asiatica). Ayu 2011, 32(2):258.

40. Gohil KJ, Patel JA, Gajjar AK: Pharmacological review on Centella asiatica: a potential herbal cure-all. Indian journal of pharmaceutical sciences 2010, 72(5):546.

41. Appa Rao M, Srinivasan K, Rao K: The effect of Mandookaparni (Centella asiatica) on the general mental ability (Medhya) of mentally retarded children. J Res Indian Med 1973, 8(9):16.

42. Mohandas Rao K, Muddanna Rao S, Gurumadhva Rao S: Centella asiatica (L.) leaf extract treatment during the growth spurt period enhances hippocampal CA3 neuronal dendritic arborization in rats. Evidence-Based Complementary and Alternative Medicine 2006, 3(3):349-357.

43. Cheung HM, Yew TW: Effects of perinatal exposure to ketamine on the developing brain. Frontiers in neuroscience 2019, 13:138.

44. Hemamalini RM: Anti stress effect of Centella asiatica leaf extract on hippocampal CA3 neurons-a quantitative study. Int J Pharmacol Clin Sci 2013, 2:25-32.

45. Soumyanath A, Zhong YP, Yu X, Bourdette D, Koop DR, Gold SA, Gold BG: Centella asiatica accelerates nerve regeneration upon oral administration and contains multiple active fractions increasing neurite elongation in-vitro. Journal of Pharmacy and Pharmacology 2005, 57(9):1221-1229.

46. Chivapat $\mathrm{S}$, Chavalittumrong $\mathrm{P}$, Tantisira $\mathrm{MH}$ : Acute and sub-chronic toxicity studies of a standardized extract of Centella asiatica ECa 233. Thai J Pharm Sci 2011, 35:55-64.

47. Wanasuntronwong A, Tantisira MH, Tantisira B, Watanabe H: Anxiolytic effects of standardized extract of Centella asiatica (ECa 233) after chronic immobilization stress in mice. Journal of ethnopharmacology 2012, 143(2):579-585.

48. Wanakhachornkrai O, Pongrakhananon V, Chunhacha P, Wanasuntronwong A, Vattanajun A, Tantisira B, Chanvorachote $\mathrm{P}$, Tantisira $\mathrm{MH}$ : Neuritogenic effect of standardized extract of Centella asiatica ECa233 on human neuroblastoma cells. BMC complementary and alternative medicine 2013, 13(1):204.

49. Zhang X, Wu J, Dou Y, Xia B, Rong W, Rimbach G, Lou Y: Asiatic acid protects primary neurons against C2-ceramide-induced apoptosis. European journal of pharmacology 2012, 679(1-3):51-59.

50. Chao MV, Rajagopal R, Lee FS: Neurotrophin signalling in health and disease. Clinical science 2006, 110(2):167-173.

51. Omar NS, Zakaria ZAC, Mian TS, Ngah WZW, Mazlan M: Centella asiatica modulates neuron cell survival by altering caspase-9 pathway. Journal of Medicinal Plants Research 2011, 5(11):2201-2209. 